Lima, Taisa Maria Macena de; CARNEIRO, Victor Augusto Souza Antunes. A antinomia entre o aval e a outorga conjugal. Revista Eletrônica Direito e Política, Programa de Pós-Graduação Stricto Sensu em Ciência Jurídica da UNIVALI, Itajaí, v.16, n.2, $2^{\circ}$ quadrimestre de 2021. Disponível em: www.univali.br/direitoepolitica - ISSN 1980-7791.

\title{
A ANTINOMIA ENTRE O AVAL E A OUTORGA CONJUGAL
}

\author{
THE ANTINOMY BETWEEN AVAL AND THE CONJUGAL GRANTING
}

Taisa Maria Macena de Lima1

Victor Augusto Souza Antunes Carneiro²

\section{RESUMO}

Intenta com o presente artigo realizar a análise da aparente incongruência constante no Código Civil quando confrontada as normas de direito comercial e de direito de família, especialmente na regulamentação do aval. Parte do conceito moderno de crédito, e, evoluindo o raciocínio, busca demonstrar as funções dos títulos de crédito na modernidade. $\mathrm{E}$, após analisar as todas as particularidades econômicas e jurídicas - especialmente na jurisprudência do Superior Tribunal de Justiça - a respeito do aval, busca inferir a solução para antinomia entre a exigência da outorga conjugal e a natureza cambiaria da garantia prestada pelo aval.

PALAVRAS-ChAVE: Direito Empresarial, Direito de Família, Títulos de Crédito, Aval, Outorga conjugal.

\section{ABSTRACT}

This article analyzes the apparent inconsistency created by the Brazilian Civil Code concerning the regulation of commercial law and family law, especially in the regulation of the aval. Introducing the modern concept of credit, and, then, evolving some arguments, seeks to demonstrate the functions of credit titles nowadays. Also, after analyzing all the economic and legal peculiarities - specially on jurisprudence - regarding the aval, brings a solution to the dichotomy between the conjugal granting requirement and the exchange nature of the guarantee provided by the aval.

KEYWORDS: Business Law, Family Law, Credit note, Suretyship, Conjugal granting.

\footnotetext{
1 Doutora e Mestre em Direito Civil pela UFMG. Ex-bolsista do DAAD - Serviço alemão de intercâmbio acadêmico. Professora da Graduação em Direito e do Programa de Pós-graduação (mestrado e doutorado) em Direito da Faculdade Mineira de Direito na PUC Minas, em Belo Horizonte/MG/Brasil. Desembargadora Federal do Trabalho do TRT-3, em Belo Horizonte/MG/Brasil. Endereço eletrônico taisamacena@yahoo.com.br.

2 Mestrando em Direito Privado pela PUC Minas (linha: "Novos paradigmas, Sujeitos e Direitos"), em Belo Horizonte/MG/Brasil. Especialista em Direito de Empresa pelo IEC PUC-Minas. Auditor da $4^{a}$ comissão de futebol amador do Tribunal de Justiça Desportiva de Minas Gerais (TJD/MG). Membro da Comissão de Admissibilidade e Instrução do Processo Ético-disciplinar do Tribunal de Ética e Disciplina da OAB/MG. Advogado e professor. Endereço eletrônico: carneiro.vasac@gmail.com.
} 
Lima, Taisa Maria Macena de; CARNEIRO, Victor Augusto Souza Antunes. A antinomia entre o aval e a outorga conjugal. Revista Eletrônica Direito e Política, Programa de Pós-Graduação Stricto Sensu em Ciência Jurídica da UNIVALI, Itajaí, v.16, n.2, $2^{\circ}$ quadrimestre de 2021. Disponível em: www.univali.br/direitoepolitica - ISSN 1980-7791.

\section{INTRODUÇÃO}

Os títulos de crédito são meios, essencialmente jurídicos, graças aos quais passou a ser possível a circulação de riquezas que não se ligam ao tempo e espaço atual. A partir de sua criação foi possível circular riquezas futuras, que ainda serão percebidas.

A razão dessas consequências não guarda correspondência tão somente na definição jurídica, na qual ele representa o direito à prestação do devedor ${ }^{3}$; está vinculada especialmente com a origem da palavra crédito. Aliás, decorre muito mais de sua etimologia, do que da finalidade literal estampada no conceito.

Crédito deriva-se do latim, creditum, particípio do passado de credere, que, em uma tradução livre, se equivale a "acreditar, confiar, ter fé". Com isso, o título de crédito, indubitavelmente, tende a expressar uma relação que está pautada na confiança. Há, inclusive, defesa da doutrina pela divisão da confiança em duas: a confiança objetiva, em que o credor acredita que o devedor possui capacidade econômico-financeira de satisfazer a prestação ${ }^{4}$; e a confiança subjetiva, o otimismo nos valores morais do devedor, pelo que ele aparenta ser ${ }^{5}$.

No entanto, a confiança entre as partes, por si só, não basta. É necessário que outro elemento constituinte do crédito esteja presente, qual seja: o tempo. Há necessidade de se presenciar o comprometimento com a efetivação da prestação futura.

Cotidianamente, utiliza-se o crédito, sem, contudo, perceber a busca por estes elementos que o constituem. É, pois, bastante intuitivo a análise da presença da confiança e da expectativa do tempo para se conceder e se buscar o crédito. Sempre que há a formalização de um negócio jurídico que tenha uma obrigação de transferência de riquezas com termo no futuro, estar-se-á diante de efetiva concessão de crédito.

\footnotetext{
3 BULGARELLI, Waldirio. Títulos de Crédito. 14. Ed. São Paulo, Atlas, 1998, p. 22.

4 ROSA JÚNIOR, Luiz Emygdio da. Títulos de Crédito. 4. Ed. Rio de Janeiro: Renovar, 2006, p.3.

5 TOMAZETTE, Marlon. Curso de Direito Empresarial: Títulos de Crédito - Volume 2. 5 ed. São Paulo: Atlas, 2014, p.3.
} 
Lima, Taisa Maria Macena de; CARNEIRO, Victor Augusto Souza Antunes. A antinomia entre o aval e a outorga conjugal. Revista Eletrônica Direito e Política, Programa de Pós-Graduação Stricto Sensu em Ciência Jurídica da UNIVALI, Itajaí, v.16, n.2, $2^{\circ}$ quadrimestre de 2021. Disponível em: www.univali.br/direitoepolitica - ISSN 1980-7791.

Principalmente diante da massificação dos negócios no cenário atual do mundo globalizado e virtual, graças a evolução dos meios de comunicação, o crédito toma frente. Em razão de suas características, possibilita o aumento das transações efetivadas, e, por isso, impulsiona a economia como um todo.

O crédito foi diretamente responsável por encorajar o aumento da demanda, que, por sua vez, incide efetivamente sobre a produção e a circulação de valores. A facilitação a seu acesso alavancou a possibilidade de negócios, não somente para os consumidores finais, mas, também, para todos os setores de produção da economia, que passaram a ter maior gama de potenciais negociadores. Trouxe consigo, desde sua criação, verdadeiro aquecimento da economia, que, por sua vez, enseja melhoria no próprio crédito, inserindo-se em uma conexão cíclica. Isto é, com o avanço da economia é esperada grande melhora na certeza de que no futuro haverá a percepção da riqueza; que simboliza o aumento na confiança, a qual, como visto, é elemento essencial para a existência do crédito.

É exatamente neste ciclo que os títulos de crédito estão inseridos. Assim como proposto por Jean Carlos Fernandes ${ }^{6}$, o mercado de crédito clama por legislações e agentes do direito que Ihe proporcionem rapidez no trato das relações, e, de igual forma, segurança na execução do crédito e das garantias.

Porém, na contramão de todo este ensejo econômico-mercadológico, surgiu o debate a respeito do aval, que, até então, era um grande signo de certeza. Com a promulgação do Código Civil vigente, suscitou o debate acerca da necessidade da outorga conjugal para prestar a garantia de natureza cambial.

E diante destas circunstâncias que se propõe o presente artigo, analisando todas as circunstâncias envolvidas na atualidade quanto ao aval e antinomia existente no que tange sua regulamentação quanto à outorga conjugal. Refletir-se-á desde que questões sociais e mercadológicas, até normativas e jurisprudenciais, de modo a buscar, de uma vez por todas, a melhor solução para tal imbróglio.

6 FERNANDES, Jean Carlos. Teoria Contemporânea dos Títulos de Crédito - Imperativos principiológicos sob a ótica das teorias pós-positivistas. Belo Horizonte: Arraes Editores, 2012, p.10. 
Lima, Taisa Maria Macena de; CARNEIRO, Victor Augusto Souza Antunes. A antinomia entre o aval e a outorga conjugal. Revista Eletrônica Direito e Política, Programa de Pós-Graduação Stricto Sensu em Ciência Jurídica da UNIVALI, Itajaí, v.16, n.2, 20 quadrimestre de 2021. Disponível em: www.univali.br/direitoepolitica - ISSN 1980-7791.

\section{OS TÍTULOS DE CRÉDITO NA CONTEMPORANEIDADE}

Numa perspectiva mais mercadológica do que jurídica, cada título de crédito é a representação da possibilidade de concessão do crédito; denotam a diversificação das várias formas de se presenciar o crédito, dando tom mais palpável e seguro às relações creditícias, pela adoção de formalidades que são intrínsecas a cada um deles. Constatação esta, que já foi percebida pelo próprio Banco Mundial, o qual indicou, na análise dos processos executivos, os títulos de crédito como sinais de eficiência, economia e transparência para fazer valer o direito do credor.

Mesmo antes da criação do nosso atual Código Civil, já existiam legislações como a Lei Uniforme de Genebra, que regulamentaram as relações cambiárias, possibilitando a utilização dos títulos de crédito tanto nacional, quanto internacionalmente. Todavia, num primeiro momento, os títulos de créditos possuíam a função de circulação de riquezas de maneira bem delimita e literal. Constituíram-se, ao longo da história, como fator de constituição e percepção de capital, alavancando o mercado por viabilizar negócios jurídicos entre para a indústria, comércio, e até mesmo para particulares.

Atualmente, diante da massificação das relações e da constante atuação de instituições financeiras, os títulos de crédito, que inicialmente possuíam finalidade de mobilização de riquezas e circulação do crédito, passou a se consagrar, ainda, como forma de financiamento. A cada dia, aumenta o número de títulos envolvendo a atuação de bancos e financiadores de crédito, em detrimento daqueles utilizados nas relações interpessoais e interempresariais.

Em verdade, inobstante esta mudança na função mais comum que os títulos de crédito tem apresentado, há de se ter em mente que foram responsáveis por oportunizar transações mercantis com participação da figura do crédito de maneira segura e ágil. E é exatamente esta a essência que os torna fomentos ao sistema de capital, e, consequentemente, do progresso econômico.

Por estas razões, na visão mais generalista, temos que: 
Lima, Taisa Maria Macena de; CARNEIRO, Victor Augusto Souza Antunes. A antinomia entre o aval e a outorga conjugal. Revista Eletrônica Direito e Política, Programa de Pós-Graduação Stricto Sensu em Ciência Jurídica da UNIVALI, Itajaí, v.16, n.2, $2^{\circ}$ quadrimestre de 2021. Disponível em: www.univali.br/direitoepolitica - ISSN 1980-7791.

O título de crédito nasce para circular e essa função de negociabilidade revela a sua importância nas áreas econômica, civil, comercial, particular e pública porque, embora disciplinado pelo direito comercial, constitui-se, na realidade, em instituto geral de direito, em instrumento de técnica jurídica, a que recorrem, para fins de financiamento, o comerciante e o lavrador, o industrial e o construtor de prédios, o particular, o Estado etc. ${ }^{7}$

Já sob o prisma do direito empresarial, o título de crédito "é o documento necessário para o exercício do direito, literal e autônomo, nele mencionado 8". Justamente coadunando com esta posição tradicionalista de Cesare Vivante que o Código Civil Brasileiro de 2002 expressou a definição legal, no art. 887:

Art. 887 CC: O título de crédito, documento necessário ao exercício do direito literal e autônomo nele contido, somente produz efeito quando preencha os requisitos da $1 \mathrm{ei}^{9}$.

Resguardados pela adoção de formalidades, atualmente, são meios simples e rápidos para a circulação de riquezas mobiliárias, por meio de documentos cambiários. E é exatamente em razão da certeza e da segurança conferida aos títulos de crédito que estes se tornaram tão bem-sucedidos, sobretudo, no meio empresarial corporativo.

Porém, para que efetivamente possam desempenhar seu papel, é necessário que estejam sendo respeitados, além da formalidade, uma série de princípios.

O primeiro princípio, e talvez o mais óbvio deles, a cartularidade, indica que o título tem que existir enquanto documento, sendo que sua origem remonta a ideia de cártula, em latim chartula, no sentido de que a apresentação do documento seria essencial para o exercício do direito. Mais recentemente, porém, não se requer a existência corpórea do título, uma vez que já existem títulos virtuais; tendo assim, reformulado a ideia, adequando-a ao pensamento de que o título de

\footnotetext{
7 ROSA JÚNIOR, Luiz Emygdio da. Títulos de Crédito. 4. Ed. Rio de Janeiro: Renovar, 2006, p. 49. 8 RAMOS, André Luiz Santa Cruz. Direito Empresarial Esquematizado. $5^{\circ}$ ed. rev., atual e ampla. Rio de Janeiro: Forense, 2015, p. 445.

9 BRASIL. Código Civil de 2002. Lei no 10.406, de 10 de janeiro de 2002. Brasília, DF: Senado Federal, 2002.
} 
Lima, Taisa Maria Macena de; CARNEIRO, Victor Augusto Souza Antunes. A antinomia entre o aval e a outorga conjugal. Revista Eletrônica Direito e Política, Programa de Pós-Graduação Stricto Sensu em Ciência Jurídica da UNIVALI, Itajaí, v.16, n.2, $2^{0}$ quadrimestre de 2021. Disponível em: www.univali.br/direitoepolitica - ISSN 1980-7791.

crédito deve estar transmutado em um documento, físico ou eletrônico, de forma que o crédito apenas circulará com a mudança da titularidade do documento.

Outro princípio se vincula à literalidade, também conhecida como completude. Esta, por sua vez, indica que somente o que se encontra expresso na cártula terá validade, isto é, o direito deve ser delimitado. O que não está expressamente consignado no título de crédito não produz consequência nas relações jurídicocambiais $^{10}$.

Ainda, a autonomia do título determina que cada pessoa que a ele se vincula passa a ter obrigação independente das demais. O art. 70 da Lei Uniforme de Genebra ${ }^{11}$ prevê especificamente que em casos de nulidade de uma das obrigações, não existe prejuízo algum para as demais, surgindo assim, o que é conhecido como a inoponibilidade de exceções pessoais.

E, por fim, deverão obedecer ao princípio da tipicidade, o qual prevê que cada título de crédito que tiver lei específica regulando-o deverá respeitar todos os seus requisitos para que seja possível a percepção, não somente de sua existência, mas, também, de sua validade.

\section{O INSTITUTO DO AVAL NO DIREITO CAMBIÁRIO BRASILEIRO}

\subsection{Conceito de Aval}

A Neste contexto de inúmeros pormenores essenciais para a configuração da certeza e da segurança que se espera dos títulos de crédito, surge a figura de mais um fator colaborativo para o êxito destas figuras jurídicas. O aval é a garantia de caráter cambial, autônoma em relação a qualquer outra obrigação, e, por isto, incorporada ao título, tendo como função precípua o reforço ao crédito cambiário, e consequentemente, a credibilidade dos títulos.

\footnotetext{
10 COELHO, Fábio Ulhôa. Manual de Direito Comercial. 20. Ed. São Paulo: Saraiva, 2008, p.234.

11 BRASIL. Decreto no. 57.663, de 24 de janeiro de 1966. Promulga as Convencõos para adoção de uma lei uniforme em matéria de letras de câmbio e notas promissórias. Disponível em: <http://www.planalto.gov.br/ccivil_03/decreto/Antigos/D57663.htm>. Acessado em 15 ago. 2018.
} 
Lima, Taisa Maria Macena de; CARNEIRO, Victor Augusto Souza Antunes. A antinomia entre o aval e a outorga conjugal. Revista Eletrônica Direito e Política, Programa de Pós-Graduação Stricto Sensu em Ciência Jurídica da UNIVALI, Itajaí, v.16, n.2, $2^{0}$ quadrimestre de 2021. Disponível em: www.univali.br/direitoepolitica - ISSN 1980-7791.

O doutrinador Gladston Mamede, assim define: "Trata-se duma declaração unilateral por meio da qual alguém (o avalista) assume a solidariedade passiva de certa obrigação constante do título de crédito. O avalista garante a obrigação assumida pelo avalizado e não a pessoa deste ${ }^{12 " .}$

Fábio Ulhoa Coelho dispõe que "o aval é o ato cambiário pelo qual uma pessoa (avalista) se compromete a pagar título de crédito, nas mesmas condições que um devedor deste título (avalizado ${ }^{13}$ )". Já Willie Duarte Costa também define aval em seu livro: "aval é a declaração cambial, eventual e sucessiva, pela qual o signatário responde pelo título de crédito ${ }^{14 " .}$.

\subsection{Características e peculiaridades do Aval}

Como esperado de todas as questões envolvendo título de crédito, o Aval é um instituto que é caracterizado de forma cerrada e literal. As principais características desta modalidade de título de crédito são: caráter unilateral, autonomia, equivalência e formalidade. A primeira característica também é definida no livro de Gladston Mamede (2012):

Cuida-se de ato jurídico unilateral: a afirmação de seu autor, o avalista, de que saldará o débito garantido, quando exigível, sendo que o aval pode ser dado em qualquer tempo, mesmo após o vencimento do título, sendo iguais os efeitos à dação da garantia antes do seu vencimento ${ }^{15}$.

Este título é autônomo, pois o avalista não pode se valer das características pessoais do avalizado, bastando:

(...) o vencimento da obrigação, sem seu adimplemento, para que a obrigação do avalista se torne exigível, estabelecendose entre avalista e avalizado, uma relação de solidariedade passiva, passando a ocupar o mesmo plano, a mesma posição

\footnotetext{
12 MAMEDE, Gladston. Direito Empresarial Brasileiro: Títulos de Crédito - Volume 3. 7 ed. São Paulo: Atlas, 2012, p.95.

13 COELHO, Fábio Ulhôa. Manual de Direito Comercial. 20. Ed. São Paulo: Saraiva, 2008, p. 410.

14 COSTA, Wille Duarte. Títulos de crédito. 4. ed. Belo Horizonte: Del Rey, 2007, p. 199.

15 MAMEDE, Gladston. Direito Empresarial Brasileiro: Títulos de Crédito - Volume 3. 7 ed. São Paulo: Atlas, 2012, p.95.
} 
Lima, Taisa Maria Macena de; CARNEIRO, Victor Augusto Souza Antunes. A antinomia entre o aval e a outorga conjugal. Revista Eletrônica Direito e Política, Programa de Pós-Graduação Stricto Sensu em Ciência Jurídica da UNIVALI, Itajaí, v.16, n.2, $2^{\circ}$ quadrimestre de 2021. Disponível em: www.univali.br/direitoepolitica - ISSN 1980-7791.

$$
\text { diante do credor }{ }^{16} \text {. }
$$

Equivalência, ou solidariedade, consiste em o avalista ser devedor do título nas mesmas proporções do avalizado, ou seja:

O credor tem o direito de exigir de qualquer um dos coobrigados o pagamento da dívida inteira; é solidariedade que resulta da lei (artigo 265 do Código Civil). O credor tem direito a exigir e receber de um, alguns ou todos os devedores, parcial ou totalmente, a dívida comum; (...) São múltiplos os obrigados, mas uno o crédito $^{17}$.

A última característica é a formalidade, qual seja, "para que a garantia se efetive, é fundamental que o avalista declare a sua vontade por escrito ${ }^{18 " .}$. A doutrina não somente a define, mas, ainda, demonstra como é feita esta declaração de vontade do avalista: "Para agilizar e simplificar o aval, entende-se que a simples assinatura do beneficiário na face (anverso) do título é suficiente para representar o aval ${ }^{19 "}$, conhecido por aval em branco.

Ademais, há uma segunda forma de formalizar o aval, qual seja: "(...) a assinatura do verso (dorso) do título, desde que acompanhada de alguma expressão que demonstre que a intenção ali era garantir o pagamento do título (por aval, por garantia...), não havendo qualquer fórmula solene ${ }^{20 "}$, chamado de aval em preto.

Diante de todas estas características, nota-se a diferença existente entre o aval e a fiança, isto é, ao contrário da fiança, o aval não possui relação de acessoriedade face a outra obrigação. Muito antes, pelo contrário: o aval é completamente independente e puramente objetivo, sendo garantia que recai não sobre a pessoa

\footnotetext{
16 MAMEDE, Gladston. Direito Empresarial Brasileiro: Títulos de Crédito - Volume 3. 7 ed. São Paulo: Atlas, 2012, p.96.

17 MAMEDE, Gladston. Direito Empresarial Brasileiro: Títulos de Crédito - Volume 3. 7 ed. São Paulo: Atlas, 2012, p.96.

18 TOMAZETTE, Marlon. Curso de Direito Empresarial: Títulos de Crédito - Volume 2. 5 ed. São Paulo: Atlas, 2014, p. 126.

19 TOMAZETTE, Marlon. Curso de Direito Empresarial: Títulos de Crédito - Volume 2. 5 ed. São Paulo: Atlas, 2014, p. 126.

20 TOMAZETTE, Marlon. Curso de Direito Empresarial: Títulos de Crédito - Volume 2. 5 ed. São Paulo: Atlas, 2014, p. 127.
} 
Lima, Taisa Maria Macena de; CARNEIRO, Victor Augusto Souza Antunes. A antinomia entre o aval e a outorga conjugal. Revista Eletrônica Direito e Política, Programa de Pós-Graduação Stricto Sensu em Ciência Jurídica da UNIVALI, Itajaí, v.16, n.2, 20 quadrimestre de 2021. Disponível em: www.univali.br/direitoepolitica - ISSN 1980-7791.

do avalizado, mas sim, sobre a obrigação de pagar constante no título de crédito. "O aval é in rem, não in personam".

A doutrina empresarialista é firme ao distinguir os dois institutos, sobretudo, destacando as particularidades do aval enquanto garantia que se vincula ao direito cambiário e seus princípios:

\begin{abstract}
Apesar de o aval e fiança serem garantias pessoas ou fidejussórias, esses dois institutos, conforme já registrado nesta obra, não se confundem, sendo consideráveis as diferenças existentes entre eles. A fiança, garantia fidejussória acessória, trata-se de um instituto regulado pelo Direito Comum - Código Civil, arts. 818 a 839. Já o aval, garantia cambiária autônoma e independente, é instituto próprio do Direito Cambiário, sendo que sempre terá natureza comercial e somente pode ser dado no próprio título de crédito. O fato de o Código Civil de 2002 também dispor sobre esse instituto não lhe retira a característica de garantia, eminentemente, cambiária e, por isso, prevalece a sua função e os seus princípios ${ }^{22}$.
\end{abstract}

Com isto, resume-se o regramento que é dado pelo Código Civil, lei geral que regulamenta o aval na falta de previsões em leis especiais:

Art. 897 CC: O pagamento de título de crédito, que contenha obrigação de pagar soma determinada, pode ser garantido por aval.

Parágrafo único. É vedado o aval parcial.

Art. 898 CC: O aval deve ser dado no verso ou no anverso do próprio título.

§ 10 Para a validade do aval, dado no anverso do título, é suficiente a simples assinatura do avalista.

$\S 20$ Considera-se não escrito o aval cancelado.

Art. 899 CC: O avalista equipara-se àquele cujo nome indicar;

\footnotetext{
21 MENDONÇA, José Xavier Carvalho de. Tratado de Direito Comercial Brasileiro. 2. Ed. Rio de Janeiro: Freitas Bastos, 1934, p. 319.

22 MATTOS, Sílvia Ferreira Persechini. Outorga Conjugal no Aval. Belo Horizonte: Del Rey, 2012 , p. 175.
} 
Lima, Taisa Maria Macena de; CARNEIRO, Victor Augusto Souza Antunes. A antinomia entre o aval e a outorga conjugal. Revista Eletrônica Direito e Política, Programa de Pós-Graduação Stricto Sensu em Ciência Jurídica da UNIVALI, Itajaí, v.16, n.2, $2^{\circ}$ quadrimestre de 2021. Disponível em: www.univali.br/direitoepolitica - ISSN 1980-7791.

na falta de indicação, ao emitente ou devedor final.

$\S 1^{\circ}$ Pagando o título, tem o avalista ação de regresso contra o seu avalizado e demais coobrigados anteriores.

$\S 20$ Subsiste a responsabilidade do avalista, ainda que nula a obrigação daquele a quem se equipara, a menos que a nulidade decorra de vício de forma ${ }^{23}$.

Portanto, o aval, enquanto garantia cambial, é disciplinado em normas que prezam por maior literalidade, explicitando seus caracteres e requisitos mínimos com maior clareza possível. Busca-se, por meio disto, maior segurança jurídica, a qual, apesar de ser princípio basilar de todo ordenamento jurídico, nesta seara, se apresenta com maior destaque.

Isto porque, sem tais limites bem estabelecidos, o instituto poderia estar fadado ao desuso ou insucesso; a garantia perderia seu sentido se suscetível a discussão e a exegese interpretativa, seja das partes, seja de terceiros, até mesmo de eventual julgador.

\subsection{O Aval como fator de incremento econômico}

Além da pura normatização do instituto do aval, há de se destacar a função desempenhada por ele enquanto fator de incremento de certeza do cumprimento das obrigações previstas nos títulos de crédito. Como toda garantia, o aval prestase a demonstrar maior segurança no cumprimento futuro de uma prestação, que, na maioria das vezes, é monetária, sujeitando o patrimônio de terceiros, além do daquele que assumiu originalmente o compromisso.

Principalmente por indicar uma obrigação autônoma, e não solidária ou subsidiária a principal, o aval se revela como forte incremento a circulação dos títulos de crédito, e das riquezas neles presentes. Esta consequência é, inclusive, reconhecida na doutrina:

23 BRASIL. Código Civil de 2002. Lei no 10.406, de 10 de janeiro de 2002. Brasília, DF: Senado Federal, 2002. 
Lima, Taisa Maria Macena de; CARNEIRO, Victor Augusto Souza Antunes. A antinomia entre o aval e a outorga conjugal. Revista Eletrônica Direito e Política, Programa de Pós-Graduação Stricto Sensu em Ciência Jurídica da UNIVALI, Itajaí, v.16, n.2, $2^{\circ}$ quadrimestre de 2021. Disponível em: www.univali.br/direitoepolitica - ISSN 1980-7791.

Conforme já destacado, nesta obra, sem o instituto dos títulos de crédito, a circulação de riquezas por meio do crédito e, portanto, a facilidade e agilidade nas operações estariam comprometidas. Isso porque, ao contrário do sistema de cessão de crédito - regido pelo direito civil -, os títulos de crédito, em razão de seus princípios e elementos próprios, permitem a certeza de seu direito e a segurança na sua circulação, atendendo, portanto, as necessidades da economia.

O aval, declaração unilateral de vontade, trouxe ainda aos títulos de crédito uma maior segurança, mormente porque, como as demais declarações cambiárias, é uma garantia autônoma e independente de qualquer citação ${ }^{24}$.

Por tudo isso, é certo dizer que o legislador pátrio possuiu grande preocupação não somente com a facilitação à circulação dos títulos, sem que significasse na diminuição da segurança para o recebimento da riqueza neles expressa. Apesar disso, por mais direta que seja esta conclusão, ela cria uma antinomia enorme quando sopesada ao lado de outra grande preocupação ao se criar o regulamento civil.

\section{A ANTINOMIA ENTRE AS PROTEÇÕES CAMBIÁRIAS DO AVAL E A EXIGÊNCIA DA OUTORGA CONJUGAL}

Desde o início da vigência da Lei no 10.406/2002 25 existem diversos questionamentos acerca da inserção de normas em matéria comercial no atual Código Civil Brasileiro. Pretende-se realizar a integração entre o Direito Comercial e o Direito Civil, mas, todavia, após a promulgação da lei sobreveio numeroso arsenal de debates como consequência natural da verificação de inconsistências nesta pretensão de abarcar áreas distintas do Direito. É de se dizer, pois, que a integração se limitou à formalidade legislativa, em detrimento da congruência material; isto é, em que pese a existência da lei que englobou disposições de duas

\footnotetext{
24 MATTOS, Sílvia Ferreira Persechini. Outorga Conjugal no Aval. Belo Horizonte: Del Rey, 2012 , p. 175.

25 BRASIL. Código Civil de 2002. Lei no 10.406, de 10 de janeiro de 2002. Brasília, DF: Senado Federal, 2002.
} 
Lima, Taisa Maria Macena de; CARNEIRO, Victor Augusto Souza Antunes. A antinomia entre o aval e a outorga conjugal. Revista Eletrônica Direito e Política, Programa de Pós-Graduação Stricto Sensu em Ciência Jurídica da UNIVALI, Itajaí, v.16, n.2, $2^{\circ}$ quadrimestre de 2021. Disponível em: www.univali.br/direitoepolitica - ISSN 1980-7791.

searas do direito, verificam-se inconsistências quanto ao conteúdo das normas dentro do próprio código.

Neste mesmo sentido, Wille Duarte Costa teceu fortes, porém pertinentes, críticas a frustrada tentativa de abrangência do Código Civil. Veja-se:

Não entendemos mesmo por qual razão foram introduzidas normas sobre títulos de crédito, criando disposições em tudo supérfluas para não dizer desnecessárias, que não melhoraram tais títulos, na medida em que foram mantidas as atuais e vigentes disposições sobre os títulos típicos cambiais e cambiariformes. A pretensão não foi a unificação dos Códigos e a absorção do Direito Comercial pelo Civil? Por que, então, a dicotomia estabelecendo normas diferentes das disciplinas pelo Direito Cambiário, mantendo-se este?

Melhor seria que toda essa matéria fosse extirpada do novo Código, pois sua presença neste estatuto é injustificável em todos os sentidos. O novel legislador não uso da mínima cautela, não se apercebendo, ou não querendo aperceber-se, de que a matéria de títulos de crédito está de há muito solidificada por uma massa perfeitamente compreensível de normas em nosso direito ${ }^{26}$.

O que em um primeiro momento parecia adequado, passa a ser dicotômico, pelo descuido do legislador ao tratar do conteúdo das normas. Isto, porque, em capítulo posterior ao regramento cambiário, o códex civilista se debruça sobre a tutela da família, e, ao fazê-lo, cria uma grande incongruência entre as normas e os princípios que regem o aval, e que vem se estendendo há tempos.

É exigido pelo Direito de Família a expressa autorização do cônjuge, sendo o avalista casado em regime que não a separação absoluta:

Art. 1.647. Ressalvado o disposto no art. 1.648, nenhum dos cônjuges pode, sem autorização do outro, exceto no regime da separação absoluta:

I - alienar ou gravar de ônus real os bens imóveis;

II - pleitear, como autor ou réu, acerca desses bens ou direitos;

${ }^{26}$ COSTA, Wille Duarte. Títulos de crédito. 4. ed. Belo Horizonte: Del Rey, 2007, p. 64. 
Lima, Taisa Maria Macena de; CARNEIRO, Victor Augusto Souza Antunes. A antinomia entre o aval e a outorga conjugal. Revista Eletrônica Direito e Política, Programa de Pós-Graduação Stricto Sensu em Ciência Jurídica da UNIVALI, Itajaí, v.16, n.2, $2^{\circ}$ quadrimestre de 2021. Disponível em: www.univali.br/direitoepolitica - ISSN 1980-7791.

III - prestar fiança ou aval;

IV - fazer doação, não sendo remuneratória, de bens comuns, ou dos que possam integrar futura meação.

Parágrafo único. São válidas as doações nupciais feitas aos filhos quando casarem ou estabelecerem economia separada ${ }^{27}$.

Sendo assim, o aval, enquanto garantia cambial, passa a estar condicionado a satisfação de um requisito legal que se descumprido, supostamente, viciaria sua validade. E justamente neste ínterim que se instaurou o questionamento: seria nulo o aval prestado sem a outorga conjugal?

Mesmo estando previsto que na injustificada recusa da vênia conjugal possa ser suprimida judicialmente, é bastante desconfortável pensar que um juiz terá o condão de sobrepesar as razões pessoais para que uma pessoa não queira permitir a concessão da garantia. Na vasta maioria dos casos, acaba por gerar insatisfação nos próprios jurisdicionados, seja procedente ou não o pleito, já que acaba invadindo um campo de extrema pessoalidade; chegando até a impor a sujeição do patrimônio próprio à garantia de uma obrigação.

Não bastasse essa polêmica, o debate acerca desta questão se intensifica ao se consignar que inexiste a figura do "autorizador" nos títulos de crédito. Rachel Sztajn e Haroldo Malheiros, abrigando este mesmo raciocínio, sustentam que:

[...] a legislação de títulos de crédito limita taxativamente a expressãoa da literalidade prevendo, consequentemente, somente alguns tipos específicos de posições cambiais, por meio das devidas assinaturas: sacador ou emitente, sacado/aceitante, endossante e avalista. Não existe figura do 'autorizador'. Disso decorrem dois efeitos jurídicos possíveis.

Em primeiro lugar, de acordo com a Lei Uniforme em matéria de Letra de Câmbio (Decreto 57.633/1966), os elementos constantes de sua literalidade específica constam do art. $1^{\circ}$. Estipulações não autorizadas pela Lei Uniforme recebem dois destinos: ou são consideradas não escritas (v.g. juros, art.

27 BRASIL. Código Civil de 2002. Lei no 10.406, de 10 de janeiro de 2002. Brasília, DF: Senado Federal, 2002. 
Lima, Taisa Maria Macena de; CARNEIRO, Victor Augusto Souza Antunes. A antinomia entre o aval e a outorga conjugal. Revista Eletrônica Direito e Política, Programa de Pós-Graduação Stricto Sensu em Ciência Jurídica da UNIVALI, Itajaí, v.16, n.2, $2^{0}$ quadrimestre de 2021. Disponível em: www.univali.br/direitoepolitica - ISSN 1980-7791.

50, $2^{a}$ alínea; endosso condicionado, art. 12, $1^{\text {a }}$ alínea) ou são nulas (v.g. endosso parcial, art. 12, $2^{a}$ alínea). Aplicandose tais regras para o aval, a 'autorização' do cônjuge será considerada não escrita ou nula, levando indiferentemente, a sua falta de efeito cartular ${ }^{28}$.

Neste norte, a outorga constituiria declaração cambiária que não possui nenhum sustentáculo legal. O Direito pátrio disciplina como declarações cambiárias uma variedade de formas pelas quais uma pessoa assume posição no título de crédito. Saque ou emissão, a depender do título de crédito, será a declaração originária e que faz nascer o título; aceite, declaração de assunção da obrigação da qual depende alguns títulos; endosso, forma de circulação do título pela transferência a outrem; e o aval, modo pelo qual se vincula ao título na condição de garantidor dos obrigados ou da obrigação constante no título como um todo.

Ter-se-ia, por estas razões, duas situações: a) a autorização seria considerada nula ou não escrita, por não suprir todas as normas legais e violar frontalmente o princípio da formalidade (Art. $887\left(\mathrm{CC}^{29}\right.$ ); b) a outorga seria, automaticamente, reconhecida como aval simultâneo, obrigando os cônjuges solidariamente ao adimplemento da riqueza ilustrada pelo título, quando de seu vencimento. Sendo que destas, mais acertada está a segunda, pois apresenta melhor congruência entre a realidade pretendida pelas partes constituintes do título e o Direito que rege o negócio jurídico.

Inobstante o enorme diálogo que possa ser travado entre as opções apresentadas, é imperioso reconhecer que a preocupação com a garantia dos títulos, infelizmente, acabou levando à tona uma restrição a seu acesso. Ou seja, quanto mais se preocupou em tutelar todas as áreas que tangenciam o civilismo, mais se prejudicou a especialidade trazida pelas normas comerciais. Tal cenário, enseja inúmeras possibilidades de se tomar decisões, ora pendendo para o Direito Comercial, ora para o Direito de Família.

\footnotetext{
28 SZTAJN, Rachel; VERÇOSA, Haroldo Malheiros Duclerc. A disciplina do aval no novo Código Civil. Revista de direito mercantil, industrial, econômico e financeiro n. 128. São Paulo: Malheiros, outubrodezembro/ 2002, p. 33-40.

${ }^{29}$ BRASIL. Código Civil de 2002. Lei n 10.406, de 10 de janeiro de 2002. Brasília, DF: Senado Federal, 2002.
} 
Lima, Taisa Maria Macena de; CARNEIRO, Victor Augusto Souza Antunes. A antinomia entre o aval e a outorga conjugal. Revista Eletrônica Direito e Política, Programa de Pós-Graduação Stricto Sensu em Ciência Jurídica da UNIVALI, Itajaí, v.16, n.2, $2^{0}$ quadrimestre de 2021. Disponível em: www.univali.br/direitoepolitica - ISSN 1980-7791.

A incerteza instaurada marca de sobremaneira a conjuntura mercadológica, afetando uma das primordiais funções ao qual se destinam os títulos de crédito, a circulação de riquezas. A possibilidade de se questionar a validade da garantia, e a inexistência de unicidade de posicionamento, enseja dúvida sobre a efetividade do próprio título e do cumprimento da obrigação constante nele. $\mathrm{E}$, embasando neste ponto, a reação no sentido de desaprovar a antinomia não era uma consequência impensável:

No entanto, a exigência da autorização prévia do cônjuge para que o outro possa dar aval, indubitavelmente, afeta a função primordial dos títulos de crédito que é a dinamicidade e a rapidez de sua circulação, bem como as características eminentemente cambiárias do aval:

'De qualquer sorte, embora a legislação anterior não previsse expressamente a autorização conjugal para a concessão de aval, fato é que muito já se discutiu, na doutrina, sobre essa questão. Nada originais são, com efeito, as críticas que se manifestam contrariamente à exigência legal, o que, a propósito, ganha adesão deste texto. É difícil conceber uma exigência de tal monta, manifestamente contrária aos princípios sobre os quais repousam a rapidez e a segurança da circulação cambiária. Como conciliar com tais princípios uma exigência que obriga os adquirentes do título a procederem a uma indagação prévia, fora dele, a respeito do estado civil dos respectivos avalistas? A proteção do patrimônio do casal é uma aspiração acima de tudo louvável, mas é contraproducente querer realizá-la tornando praticamente inacessível ao cônjuge casado na condição acima referida o uso de um instituto precioso como título de crédito.

O ditame aí está, e dele não se pode afasta, restando apenas apontar alguns caminhos para que a exigência legal não interfira na rotina empresarial - dinâmica e célere, por natureza - a ponto de se tornar, em determinadas ocasiões, um verdadeiro empecilho à consecução de seu fim, que é o lucro ${ }^{30}$.'

30 MATTOS, Sílvia Ferreira Persechini. Outorga Conjugal no Aval. Belo Horizonte: Del Rey, 2012, p. 177. 
Lima, Taisa Maria Macena de; CARNEIRO, Victor Augusto Souza Antunes. A antinomia entre o aval e a outorga conjugal. Revista Eletrônica Direito e Política, Programa de Pós-Graduação Stricto Sensu em Ciência Jurídica da UNIVALI, Itajaí, v.16, n.2, $2^{\circ}$ quadrimestre de 2021. Disponível em: www.univali.br/direitoepolitica - ISSN 1980-7791.

Instaurada a antinomia na própria norma positivada, é enorme o prejuízo para uma eficaz forma de garantia à circulação do crédito, porquanto apresentar-se-á como verdadeiro agravamento do risco do credor, sobretudo, diante da premente tendência a favorecer o âmbito familiar, em detrimento do comercial. Por isto, inarredável serão os constantes aumentos nos custos de transação e nos juros, que, em ciclo vicioso, predestinarão o fim do instituto garantidor cambiário.

Deverá haver uma pacificação no entendimento sobre o Direito pátrio para se extirpar os possíveis questionamentos, e respaldar a segurança buscada com a utilização dos títulos de crédito.

\subsection{A evolução jurisprudencial na solução da antinomia e o paradigma criado pelo} Recurso Especial no 1526560/MG

Justamente na tentativa de pacificar o embate travado é que os cidadãos colocaram sub judicie a questão. Desde de o início da vigência do atual Código Civil, ocorreu o embate de interesses, estando de um lado os credores - titulares do direito de demandarem os avalistas coobrigados - e, de outro, os avalistas. Enquanto os credores se fixaram em bases cambiárias, defendendo sempre pela validade do aval, independente da presença da autorização conjugal, os avalistas, ou melhor dizendo, seus cônjuges, buscaram os fundamentos do Direito de Família para sustentar a nulidade do aval prestado.

Posta em juízo, a discussão quedou-se por ainda mais tempo controvertida; isto, porque, dentro do próprio Superior Tribunal de Justiça criaram-se de polaridades antagônicas. Assim, dentro da própria casa uniformizadora da jurisprudência em nível nacional, ocorreu, durante muito tempo, um embate de entendimentos.

A discussão se estabeleceu em torno da interpretação do art. 1.647, inciso III, do $\mathrm{CC} / 2002^{31}$. Buscou-se saber se o consentimento conjugal seria ou não requisito de validade do aval, quando o avalista for casado em outros regimes que não o da separação absoluta.

\footnotetext{
31 BRASIL. Código Civil de 2002. Lei no 10.406, de 10 de janeiro de 2002. Brasília, DF: Senado Federal, 2002.
} 
Lima, Taisa Maria Macena de; CARNEIRO, Victor Augusto Souza Antunes. A antinomia entre o aval e a outorga conjugal. Revista Eletrônica Direito e Política, Programa de Pós-Graduação Stricto Sensu em Ciência Jurídica da UNIVALI, Itajaí, v.16, n.2, $2^{\circ}$ quadrimestre de 2021. Disponível em: www.univali.br/direitoepolitica - ISSN 1980-7791.

\subsubsection{A consolidação do entendimento da Quarta Turma do Superior Tribunal de Justiça}

A Quarta Turma da Corte Superior sempre se posicionou no sentido de que a garantia do aval em cédula de crédito comercial dispensa a outorga do cônjuge. Sempre se privilegiou a validade do aval enquanto garantia cambiária, justamente com a preocupação de não se esvaziar por completo o instituto, e, com isso, incitar a crise dos títulos de crédito.

Sobrelevando, especialmente, as características imanentes dos institutos do direito cambiário, o último, e talvez mais significativo, julgado restou assim ementado:

DIREITO CAMBIÁRIO E PROCESSUAL CIVIL. RECURSO ESPECIAL. REVELIA. EFEITOS RELATIVOS. AVAL. NECESSIDADE DE OUTORGA UXÓRIA OU MARITAL. DISPOSIÇÃO RESTRITA AOS TÍTULOS DE CRÉDITO INOMINADOS OU ATÍPICOS. ART. 1.647, III, DO CC/2002. INTERPRETAÇÃO QUE DEMANDA OBSERVÂNCIA À RESSALVA EXPRESSA DO ART. 903 DO CC E AO DISPOSTO NA LUG ACERCA DO AVAL. REVISÃO DO ENTENDIMENTO DO COLEGIADO. COGITAÇÃO DE APLICAÇÃO DA REGRA NOVA PARA AVAL DADO ANTES DA VIGÊNCIA DO NOVO CC. MANIFESTA INVIABILIDADE.

1. Os efeitos da revelia - presunção de veracidade dos fatos alegados pelo autor - são relativos e não conduzem, necessariamente, ao julgamento de procedência dos pedidos, devendo o juiz atentar-se para os elementos probatórios presentes nos autos, para formação de sua convicção.

2. Diversamente do contrato acessório de fiança, o aval é ato cambiário unilateral, que propicia a salutar circulação do crédito, ao instituir, dentro da celeridade necessária às operações a envolver títulos de crédito, obrigação autônoma ao avalista, em benefício da negociabilidade da cártula. Por isso, o aval "considera-se como resultante da simples assinatura" do avalista no anverso do título (art. 31 da LUG), devendo corresponder a ato incondicional, não podendo sua eficácia ficar subordinada a evento futuro e incerto, porque dificultaria a circulação do título de crédito, que é a sua função precípua.

3. É imprescindível proceder-se à interpretação sistemática para a correta compreensão do art. 1.647 , III, do CC/2002, 
Lima, Taisa Maria Macena de; CARNEIRO, Victor Augusto Souza Antunes. A antinomia entre o aval e a outorga conjugal. Revista Eletrônica Direito e Política, Programa de Pós-Graduação Stricto Sensu em Ciência Jurídica da UNIVALI, Itajaí, v.16, n.2, $2^{\circ}$ quadrimestre de 2021. Disponível em: www.univali.br/direitoepolitica - ISSN 1980-7791.

de modo a harmonizar os dispositivos do Diploma civilista. Nesse passo, coerente com o espírito do Código Civil, em se tratando da disciplina dos títulos de crédito, o art. 903 estabelece que "salvo disposição diversa em lei especial, regem-se os títulos de crédito pelo disposto neste Código".

4. No tocante aos títulos de crédito nominados, o Código Civil deve ter uma aplicação apenas subsidiária, respeitando-se as disposições especiais, pois o objetivo básico da regulamentação dos títulos de crédito, no novel Diploma civilista, foi permitir a criação dos denominados títulos atípicos ou inominados, com a preocupação constante de diferençar os títulos atípicos dos títulos de crédito tradicionais, dando aos primeiros menos vantagens.

5. A necessidade de outorga conjugal para o aval em títulos inominados - de livre criação - tem razão de ser no fato de que alguns deles não asseguram nem mesmo direitos creditícios, a par de que a possibilidade de circulação é, evidentemente, deveras mitigada. A negociabilidade dos títulos de crédito é decorrência do regime jurídico-cambial, que estabelece regras que dão à pessoa para quem o crédito é transferido maiores garantias do que as do regime civil.

6. As normas das leis especiais que regem os títulos de crédito nominados, v.g., letra de câmbio, nota promissória, cheque, duplicata, cédulas e notas de crédito, continuam vigentes e se aplicam quando dispuserem diversamente do Código Civil de 2002, por força do art. 903 do Diploma civilista. Com efeito, com o advento do Diploma civilista, passou a existir uma dualidade de regramento legal: os títulos de crédito típicos ou nominados continuam a ser disciplinados pelas leis especiais de regência, enquanto os títulos atípicos ou inominados subordinam-se às normas do novo Código, desde que se enquadrem na definição de título de crédito constante no art. 887 do Código Civil.

7. Recurso especial não provido 32

Segundo o Ministro Luis Felipe Salomão, relator do Recurso Especial no 1633399/SP, "o aval, como qualquer obrigação cambiária, deve corresponder a ato incondicional, não podendo sua eficácia ficar subordinada a evento futuro e incerto, porque dificultaria a circulação do título de crédito, que é sua função

\footnotetext{
32 BRASIL. Superior Tribunal de Justiça, REsp 1633399/SP, Rel. Ministro Luis Felipe Salomão, Quarta Turma, julgado em 10/11/2016, DJe 01/12/2016.
} 
Lima, Taisa Maria Macena de; CARNEIRO, Victor Augusto Souza Antunes. A antinomia entre o aval e a outorga conjugal. Revista Eletrônica Direito e Política, Programa de Pós-Graduação Stricto Sensu em Ciência Jurídica da UNIVALI, Itajaí, v.16, n.2, $2^{\circ}$ quadrimestre de 2021. Disponível em: www.univali.br/direitoepolitica - ISSN 1980-7791.

precípua33". Outrossim, consigna que a regra do artigo 1.647 do Código Civil ${ }^{34}$ apenas poderia ser oposta caso o título de crédito fosse atípico, uma vez que, pelo princípio da especialidade, os títulos de crédito típicos ou nominados continuam a ser disciplinados pelas leis especiais de regência.

O artigo 903 do Codex civilista é bastante claro nesse sentido, por prever que "salvo disposição diversa em lei especial, regem-se os títulos de crédito pelo disposto neste Código ${ }^{35 "}$.

Justamente embasado neste posicionamento é que se desenvolveu a negativa de provimento ao recurso aviado, pois a Lei Uniforme de Genebra, recepcionada sem nenhuma ressalva pelo Decreto no 57.663/96, não condiciona a prestação e a validade do aval à autorização do cônjuge. Essa é a disciplina dada pela referida lei, e por outras tantas leis especiais:

Art. 32 Lei Uniforme de Genebra: O dador de aval é responsável da mesma maneira que a pessoa por ele afiançada. A sua obrigação mantém-se, mesmo ao caso de a obrigação que ele garantiu ser nula por qualquer razão não seja um vicio de forma. Se o dador de aval paga a letra, fica sub-rogado nos direitos emergentes da letra contra a pessoa a favor de quem foi dado o aval e contra os obrigados para com esta em virtude da letra. ${ }^{36}$

Art. 14 do Decreto-Lei no 2.044/08: O pagamento de uma letra de câmbio, independente do aceite e do endosso, pode ser garantido por aval. Para a validade do aval, é suficiente a simples assinatura do próprio punho do avalista ou do mandatário especial, no verso ou no anverso da letra. ${ }^{37}$

\footnotetext{
33 BRASIL. Superior Tribunal de Justiça, REsp 1633399/SP, Rel. Ministro Luis Felipe Salomão, Quarta Turma, julgado em 10/11/2016, DJe 01/12/2016.

34 BRASIL. Código Civil de 2002. Lei no 10.406, de 10 de janeiro de 2002. Brasília, DF: Senado Federal, 2002.

35 BRASIL. Código Civil de 2002. Lei no 10.406, de 10 de janeiro de 2002. Brasília, DF: Senado Federal, 2002.

36 BRASIL. Decreto no. 57.663, de 24 de janeiro de 1966. Promulga as Convencões para adocão de uma lei uniforme em matéria de letras de câmbio e notas promissórias. Disponível em: <http://www.planalto.gov.br/ccivil_03/decreto/Antigos/D57663.htm>. Acessado em 15 ago. 2019. 37 BRASIL. Decreto no. 2.044, de 31 de dezembro de 1908. Define a letra de caimbio e a nota promissória e regula as Operações Cambiais. Disponível em: <http://www.planalto.gov.br/ccivil_03/decreto/Historicos/DPL/DPL2044.htm>. Acessado em 15 ago. 2019.
} 
Lima, Taisa Maria Macena de; CARNEIRO, Victor Augusto Souza Antunes. A antinomia entre o aval e a outorga conjugal. Revista Eletrônica Direito e Política, Programa de Pós-Graduação Stricto Sensu em Ciência Jurídica da UNIVALI, Itajaí, v.16, n.2, 20 quadrimestre de 2021. Disponível em: www.univali.br/direitoepolitica - ISSN 1980-7791.

Art. 30 da lei 7.357/85: O aval é lançado no cheque ou na folha de alongamento. Exprime-se pelas palavras "por aval", ou fórmula equivalente, com a assinatura do avalista. Considera-se como resultante da simples assinatura do avalista, aposta no anverso do cheque, salvo quando se tratar da assinatura do emitente.

Art. 31 da lei 7.357/85: O avalista se obriga da mesma maneira que o avalizado. Subsiste sua obrigação, ainda que nula a por ele garantida, salvo se a nulidade resultar de vício de forma 38

Também é bastante clara a previsão do princípio da independência das obrigações cambiais na Lei Cambial:

Art. 43 As obrigações cambiais, são autônomas e independentes umas das outras. O significado da declaração cambial fica, por ela, vinculado e solidariamente responsável pelo aceite e pelo pagamento da letra, sem embargo da falsidade, da falsificação ou da nulidade de qualquer outra assinatura.

Art. 51. Na ação cambial, somente é admissível defesa fundada no direito pessoal do réu contra o autor, em defeito de forma do título e na falta de requisito necessário ao exercício da ação. ${ }^{39}$

Nesse sentido, requisitar a outorga do cônjuge do avalista como critério de validade do aval comprometeria, sobremaneira, a garantia imanente aos títulos de crédito, enfraquecendo-os a ponto de retirar sua aptidão à circulação. A doutrina rechaça de forma veemente essa possibilidade, ao fundamento de que a outorga enquanto condição de validade do aval confronta sua própria essência:

Ainda, sobre a incondicionalmente do aval, Rosa Jr. Ressalta que 'o aval, como qualquer obrigação cambiária, deve corresponder a um ato incondicional, não podendo sua eficácia ficar subordinada a um evento futuro e incerto porque dificultaria a circulação do título de crédito, que é sua função

\footnotetext{
38 BRASIL. Lei no 7.357, de 2 de setembro de 1985. Dispõe sobre o cheque e dá outras providências. Disponível em: <http://www.planalto.gov.br/ccivil_03/leis/l7357.htm>. Acessado em 15 ago. 2019. 39 BRASIL. Decreto no. 2.044, de 31 de dezembro de 1908. Define a letra de caimbio e a nota promissória e regula as Operações Cambiais. Disponível em: <http://www.planalto.gov.br/ccivil_03/decreto/Historicos/DPL/DPL2044.htm>. Acessado em 15 ago. 2019.
} 
Lima, Taisa Maria Macena de; CARNEIRO, Victor Augusto Souza Antunes. A antinomia entre o aval e a outorga conjugal. Revista Eletrônica Direito e Política, Programa de Pós-Graduação Stricto Sensu em Ciência Jurídica da UNIVALI, Itajaí, v.16, n.2, 20 quadrimestre de 2021. Disponível em: www.univali.br/direitoepolitica - ISSN 1980-7791.

precípua'. Ou seja, a autonomia da garantia cambiária não permite que esta seja dependente de consentimento de outrem para ter validade.

$[\ldots]$

Em suma, a exigência da outorga conjugal para se dar aval contraria o conteúdo normativo do princípio da autonomia das obrigações, positivado pela Lei Uniforme de Genebra e pela Lei do Cheque, razão pela qual o art. 1647, inciso III, do Código Civil, não se aplica aos títulos de crédito regulados pela lei cambial, ainda que subsidiariamente ${ }^{40}$.

Estes fundamentos, pois, apenas reforçam a luta por maior segurança jurídica requisitada pelas relações creditícias sob a ótica mercadológica. Entende-se ser demasiadamente arriscado possibilitar balizas na interpretação das normatizações, ou ainda, ensejar hipótese de questionamento por terceiros estranhos a relação cambial garantida. Hipóteses como estas, indubitavelmente, sempre soam negativamente perante qualquer um que busque a certeza de recebimento de crédito.

\subsubsection{A evolução jurisprudencial da Terceira Turma do Superior Tribunal de Justiça}

Na contramão deste posicionamento, a Terceira Turma, até o ano de 2017, se empenhava na análise das questões atinentes aos regimes de bens que disciplinavam os regimes de bens. Isto é, atinham-se, antes de qualquer coisa, à norma contida no Art. 1.647 do $\mathrm{CC}^{41}$, entendendo que a lei civil pretendeu garantir aos cônjuges maior segurança no controle da gestão patrimonial conjunta.

Assentava o posicionamento no ideário de que a relação marital, para além das relações intrapessoais e de convivência familiar, também abarcaria, inevitavelmente, um complexo de relações econômicas, que se transmutavam em meios de satisfação dos objetivos comuns dos casais. Principalmente pela posição da norma em abrir oportunidade para os nubentes escolherem livremente o

\footnotetext{
40 MATTOS, Sílvia Ferreira Persechini. Outorga Conjugal no Aval. Belo Horizonte: Del Rey, 2012, p. 183.

${ }^{41}$ BRASIL. Código Civil de 2002. Lei no 10.406, de 10 de janeiro de 2002. Brasília, DF: Senado Federal, 2002.
} 
Lima, Taisa Maria Macena de; CARNEIRO, Victor Augusto Souza Antunes. A antinomia entre o aval e a outorga conjugal. Revista Eletrônica Direito e Política, Programa de Pós-Graduação Stricto Sensu em Ciência Jurídica da UNIVALI, Itajaí, v.16, n.2, $2^{\circ}$ quadrimestre de 2021. Disponível em: www.univali.br/direitoepolitica - ISSN 1980-7791.

regime, salvo poucas exceções, entendia-se que deveria ser resguardado aos cônjuges a garantia de controle da gestão patrimonial do casal.

Neste ínterim, entendeu-se que apenas nos casos da separação legal de bens, em que há a celebração do pacto antenupcial prevendo este regime, e em outros em que se celebrar pacto excluindo expressamente em contrário, a validade da garantia cambiária penderia da outorga para que fosse validamente prestada. Nesse sentido, nos idos de 2009, assim se posicionou:

RECURSO ESPECIAL - AÇÃO ANULATÓRIA DE AVAL OUTORGA CONJUGAL PARA CÔNJUGES CASADOS SOB O REGIME DA SEPARAÇÃO OBRIGATÓRIA DE BENS NECESSIDADE - RECURSO PROVIDO.

1. É necessária a vênia conjugal para a prestação de aval por pessoa casada sob o regime da separação obrigatória de bens, à luz do artigo 1647, III, do Código Civil.

2. A exigência de outorga uxória ou marital para os negócios jurídicos de (presumidamente) maior expressão econômica previstos no artigo 1647 do Código Civil (como a prestação de aval ou a alienação de imóveis) decorre da necessidade de garantir a ambos os cônjuges meio de controle da gestão patrimonial, tendo em vista que, em eventual dissolução do vínculo matrimonial, os consortes terão interesse na partilha dos bens adquiridos onerosamente na constância do casamento.

3. Nas hipóteses de casamento sob o regime da separação legal, os consortes, por força da Súmula n. 377/STF, possuem o interesse pelos bens adquiridos onerosamente ao longo do casamento, razão por que é de rigor garantir-lhes o mecanismo de controle de outorga uxória/marital para os negócios jurídicos previstos no artigo 1647 da lei civil.

4. Recurso especial provido. ${ }^{42}$

\footnotetext{
42 BRASIL. Superior Tribunal de Justiça, REsp 1163074/PB, Rel. Ministro Massami Uyeda, Terceira Turma, julgado em 15/12/2009, DJe 04/02/2010.
} 
Lima, Taisa Maria Macena de; CARNEIRO, Victor Augusto Souza Antunes. A antinomia entre o aval e a outorga conjugal. Revista Eletrônica Direito e Política, Programa de Pós-Graduação Stricto Sensu em Ciência Jurídica da UNIVALI, Itajaí, v.16, n.2, $2^{\circ}$ quadrimestre de 2021. Disponível em: www.univali.br/direitoepolitica - ISSN 1980-7791.

Recentemente, porém, ocorreu uma mudança radical na forma como a Terceira Turma se posiciona. Foi a partir do julgamento do Recurso Especial de no 1526560/MG ${ }^{43}$, de relatoria do Ministro Paulo de Tarso Sanseverino, que se reestruturou a exegese dada pela corte.

O acórdão em comento restou assim ementado:

RECURSO ESPECIAL. DIREITO CAMBIÁRIO. AVAL. OUTORGA UXÓRIA OU MARITAL. INTERPRETAÇÃO DO ART. 1647, INCISO III, DO CCB, À LUZ DO ART. 903 DO MESMO ÉDITO E, AINDA, EM FACE DA NATUREZA SECULAR DO INSTITUTO CAMBIÁRIO DO AVAL. REVISÃO DO ENTENDIMENTO DESTE RELATOR.

1. O Código Civil de 2002 estatuiu, em seu art. 1647, inciso III, como requisito de validade da fiança e do aval, institutos bastante diversos, em que pese ontologicamente constituam garantias pessoais, o consentimento por parte do cônjuge do garantidor.

2. Essa norma exige uma interpretação razoável sob pena de descaracterização do aval como típico instituto cambiário.

3. A interpretação mais adequada com o referido instituto cambiário, voltado a fomentar a garantia do pagamento dos títulos de crédito, à segurança do comércio jurídico e, assim, ao fomento da circulação de riquezas, é no sentido de limitar a incidência da regra do art.1647, inciso III, do CCB aos avais prestados aos títulos inominados regrados pelo Código Civil, excluindo-se os títulos nominados regidos por leis especiais.

4. Precedente específico da Colenda 4a Turma.

5. Alteração do entendimento deste relator e desta Terceira Turma.

6. RECURSO ESPECIAL DESPROVIDO ${ }^{4}$.

\footnotetext{
43 BRASIL. Superior Tribunal de Justiça, REsp 1526560/MG, Rel. Ministro Paulo De Tarso Sanseverino, Terceira Turma, julgado em 16/03/2017, DJe 16/05/2017.

44 BRASIL. Superior Tribunal de Justiça, REsp 1526560/MG, Rel. Ministro Paulo De Tarso Sanseverino, Terceira Turma, julgado em 16/03/2017, DJe 16/05/2017.
} 
Lima, Taisa Maria Macena de; CARNEIRO, Victor Augusto Souza Antunes. A antinomia entre o aval e a outorga conjugal. Revista Eletrônica Direito e Política, Programa de Pós-Graduação Stricto Sensu em Ciência Jurídica da UNIVALI, Itajaí, v.16, n.2, $2^{\circ}$ quadrimestre de 2021. Disponível em: www.univali.br/direitoepolitica - ISSN 1980-7791.

$\mathrm{Na}$ ação que deu origem ao recurso, a autora pleiteou a declaração da nulidade do aval prestado por seu marido, uma vez que carecia de sua autorização para tanto. Em primeira instância, a ação foi julgada parcialmente procedente, tendo sido decretada a nulidade apenas em relação à autora; o posicionamento foi mantido pelo Tribunal de Justiça do Estado de Minas Gerais.

E, quando do julgamento do recurso especial que fora, ao fim, desprovido, ponderou-se exatamente a mesma preocupação da Quarta Turma do ST]: a submissão do aval, no plano de sua validade, à autorização conjugal comprometeria a capacidade de circulação garantida aos títulos de crédito e afetaria, por extensão, a sua aceitação no mercado. Acertou-se o posicionamento no sentido de que o aval é garantia cambial autônoma, não podendo se sujeitar a condição extracartular para sua validade.

O voto proferido pelo relator, a todo momento, indica a mudança de posicionamento adotado anteriormente pela turma, passando a se alinhar e, inclusive, fazer referência a acórdãos prolatados pela turma que antes era considerada polo antagônico a jurisprudência da Terceira Turma. De todo modo, mais essencial do que as saudações ao posicionamento diverso, são os próprios fundamentos formulados no decorrer do acórdão:

Bem se vê que o aval mais ainda se distancia das peculiaridades do negócio que subjaz, pois ele próprio é autônomo em relação ao crédito consubstanciado no título que, por sua vez, é autônomo em face da relação jurídica subjacente.

A submissão da validade do aval à outorga do cônjuge do avalista compromete, sobremaneira, a garantia que dimana do instituto, enfraquecendo, ao fim e ao cabo, os próprios títulos de crédito, tão aptos à circulação em face de sua, de certo modo, tranquila aceitação no mercado, tranquilidade esta a decorrer das garantias que dimanam de suas características e dos institutos cambiários que os coadjuvam, como o aval.

Ele, enquanto declaração unilateral de vontade do avalista em garantir o pagamento do valor inscrito no título, somente tem lugar em obrigações cambiárias; é, pois, instituto comercial a ser lançado apenas em títulos de crédito, diferentemente da fiança, que é contrato e poderá ser celebrada em relação a 
Lima, Taisa Maria Macena de; CARNEIRO, Victor Augusto Souza Antunes. A antinomia entre o aval e a outorga conjugal. Revista Eletrônica Direito e Política, Programa de Pós-Graduação Stricto Sensu em Ciência Jurídica da UNIVALI, Itajaí, v.16, n.2, $2^{\circ}$ quadrimestre de 2021. Disponível em: www.univali.br/direitoepolitica - ISSN 1980-7791.

qualquer negócio.

A outorga uxória ou marital compraz com o contrato de fiança, mas não com a declaração unilateral consubstanciada no aval, pois o portador do título contato algum, em regra, terá com o avalista e, menos ainda, com algum documento de identificação deste em que se evidencie o seu estado civil. Acaso mantida a orientação de que a ausência de outorga marital ou uxória do cônjuge do avalista anula, integralmente, o aval, os títulos circulando e aqueles por ventura a serem ainda emitidos terão indisfarçável decesso de segurança e de atratividade, pois poderá a vir a ser reduzida a garantia expressa na cártula e consubstanciada nos avais concedidos aos devedores principais, com a sua eventual declaração de nulidade ${ }^{45}$.

Face ao delineado, acredita-se que a partir da melhor exegese do artigo 1.649 do Código Civil ${ }^{46}$ e da sua pretensa imperiosidade quanto à outorga conjugal é possível alcançar a conclusão de que a falta da vênia conjugal não invalidará o aval, mas, sim, poderá, segundo o caso, implicar em ineficácia parcial da garantia. Não será admissível subjugar os bens pessoais e até a meação - caso haja - do cônjuge não anuente com o aval à uma eventual execução ou cobrança de valores.

A consequência jurídica, então, passa a extrapolar o plano da validade do aval, devendo a discussão se inserir no plano de sua eficácia, conforme, aliás, já fora posicionado no Enunciado 114 da I Jornada de Direito Civil do Conselho da Justiça Federal: O aval não pode ser anulado por falta da vênia conjugal, de modo que o inciso III do art. 1.647 apenas caracteriza a inoponibilidade do título ao cônjuge que não assentiu 47.

Destarte, uma vez prestado o aval, mesmo que sem a outorga conjugal, este permanecerá válido, mantendo sua higidez em razão dos princípios da cartularidade, autonomia e independência das obrigações cambiais ${ }^{48}$. Ademais,

45 BRASIL. Superior Tribunal de Justiça, REsp 1526560/MG, Rel. Ministro Paulo De Tarso Sanseverino, Terceira Turma, julgado em 16/03/2017, DJe 16/05/2017.

46 BRASIL. Código Civil de 2002. Lei no 10.406, de 10 de janeiro de 2002. Brasília, DF: Senado Federal, 2002.

47 BRASIL. Conselho Nacional de Justiça. Enunciado 114. I Jornada de Direito Civil, 2012. Disponível em: < https://www.cjf.jus.br/enunciados/enunciado/751>. Acesso em: 19 de janeiro de 2020.

48 FERNANDES, Jean Carlos. Teoria Contemporânea dos Títulos de Crédito - Imperativos principiológicos sob a ótica das teorias pós-positivistas. Belo Horizonte: Arraes Editores, 2012, p. 312. 
Lima, Taisa Maria Macena de; CARNEIRO, Victor Augusto Souza Antunes. A antinomia entre o aval e a outorga conjugal. Revista Eletrônica Direito e Política, Programa de Pós-Graduação Stricto Sensu em Ciência Jurídica da UNIVALI, Itajaí, v.16, n.2, $2^{0}$ quadrimestre de 2021. Disponível em: www.univali.br/direitoepolitica - ISSN 1980-7791.

restringirá o debate apenas ao fato de que pode ter sua eficácia comprometida, no tocante ao cônjuge dissidente, isto é, podendo, no muito, não produzir efeitos na parte que lhe cabe, seja ela patrimônio pessoal, seja ela meação.

Para tanto, será essencial a análise do caso concreto, na medida em que, segundo o regime de bens adotado pelos cônjuges, a ausência da outorga afetará distintamente o patrimônio do avalista e de seu consorte.

\subsection{Análise do plano da eficácia do aval prestado sem a vênia conjugal}

A legislação brasileira, em matéria de família, permite aos nubentes optarem por um regime de bens para regular o patrimônio a partir da criação da sociedade conjugal (Art. 1.639, $\mathrm{CC}^{49}$ ), seja em momento anterior a celebração do casamento (Art. 1.653, $\mathrm{CC}^{50}$ ), seja durante sua vigência. Esta escolha determinará como o patrimônio do casal se tornará após a contração de núpcias e como será administrado.

Além destes efeitos genéricos, haverá outros tantos específicos, onde se inserirá exatamente o plano da eficácia do aval prestado sem a chancela do cônjuge. Não caberá adentrar novamente no debate do aval prestado com a presença da vênia conjugal, porque já se enfrentou as razões pelas quais deverá se considerar a 'autorização' como aval simultâneo prestado pelo cônjuge.

No regime da comunhão parcial (Art. 1.658, $\mathrm{CC}^{51}$ ) - o qual também é o regime legal, adotado caso não haja celebração de pacto antinupcial alterando-o - os nubentes terão o casamento como marco temporal para determinar dois montes de bens. O primeiro deles, o dos bens havidos antes do matrimonio, constituirá patrimônio pessoal e, por isso, se sujeitará quando o aval for prestado. Todavia, o segundo, o dos bens adquiridos na constância do casamento, por ser patrimônio comum do casal, deverá ser respeitada a meação devida ao cônjuge não anuente.

\footnotetext{
49 BRASIL. Código Civil de 2002. Lei no 10.406, de 10 de janeiro de 2002. Brasília, DF: Senado Federal, 2002.

50 BRASIL. Código Civil de 2002. Lei no 10.406, de 10 de janeiro de 2002. Brasília, DF: Senado Federal, 2002.

${ }^{51}$ BRASIL. Código Civil de 2002. Lei no 10.406, de 10 de janeiro de 2002. Brasília, DF: Senado Federal, 2002.
} 
Lima, Taisa Maria Macena de; CARNEIRO, Victor Augusto Souza Antunes. A antinomia entre o aval e a outorga conjugal. Revista Eletrônica Direito e Política, Programa de Pós-Graduação Stricto Sensu em Ciência Jurídica da UNIVALI, Itajaí, v.16, n.2, $2^{\circ}$ quadrimestre de 2021. Disponível em: www.univali.br/direitoepolitica - ISSN 1980-7791.

De igual modo, serão estes os mesmos limiares aplicáveis quando se estiver defronte a um casal em união estável. Havendo previsão expressa da adoção do regime legal para esta situação, não é concebível se perceber consequências distintas, pois apesar de a maioria das vezes não existir uma formalização desta condição, há equiparação constitucional - §30 do Art. 226 da Constituição Federal - da união estável ao casamento para fins de proteção do Estado.

Quando da comunhão universal (Art. 1.667, CC ${ }^{52}$ ) os cônjuges formarão um único grande patrimônio comum. Desta forma, sempre haverá o respeito a meação do cônjuge que se recusar a avalizar o título, sendo este o limite da eficácia do aval.

Há de se frisar que em ambos os regimes em que há comunhão de bens (Art. 1.687, $\left.\mathrm{CC}^{53}\right)$, parcial ou universal, existem previsões legais aos Arts. 1.659 e $1.668^{54}$, que indicam bens que, independentemente do tempo em que foram adquiridos, não se comunicarão. E por não integrarem ao patrimônio do casal, se sujeitarão, em sua integralidade, a possível execução da garantia cambial.

Caso o regime adotado seja o da separação de bens ou o da participação final nos aquestos (Art. 1.672, CC ${ }^{55}$ ), sendo existente apenas o patrimônio pessoal de cada casal, não há dúvidas de que a eficácia do aval incidirá sobre o patrimônio do avalista e nada mais. Inclusive, cumpre o destaque para o fato de que sequer há exigência para prestar o aval no caso da separação de bens, por força da exceção estampada no caput do controverso Art. $1.647^{56}$ do Código Civil.

Outrossim, não obstante algumas conspirações em contrário, não parece muito acertado pretender realizar os aquestos quando da execução do aval, para também se sujeitarem a tanto, simplesmente por estar na contramão da vontade precípua para o qual o regime de bens foi criado. Por este regime permite-se que

\footnotetext{
52 BRASIL. Código Civil de 2002. Lei no 10.406, de 10 de janeiro de 2002. Brasília, DF: Senado Federal, 2002.

${ }^{53}$ BRASIL. Código Civil de 2002. Lei no 10.406, de 10 de janeiro de 2002. Brasília, DF: Senado Federal, 2002.

${ }^{54}$ BRASIL. Código Civil de 2002. Lei no 10.406, de 10 de janeiro de 2002. Brasília, DF: Senado Federal, 2002.

55 BRASIL. Código Civil de 2002. Lei no 10.406, de 10 de janeiro de 2002. Brasília, DF: Senado Federal, 2002.

${ }^{56}$ BRASIL. Código Civil de 2002. Lei no 10.406, de 10 de janeiro de 2002. Brasília, DF: Senado Federal, 2002.
} 
Lima, Taisa Maria Macena de; CARNEIRO, Victor Augusto Souza Antunes. A antinomia entre o aval e a outorga conjugal. Revista Eletrônica Direito e Política, Programa de Pós-Graduação Stricto Sensu em Ciência Jurídica da UNIVALI, Itajaí, v.16, n.2, $2^{\circ}$ quadrimestre de 2021. Disponível em: www.univali.br/direitoepolitica - ISSN 1980-7791.

durante a vivencia conjugal possa cada cônjuge administrar seus bens livremente, e apenas realizar a reunião dos bens adquiridos onerosamente na constância matrimonial - aquestos - para fins de divisão em caso de divórcio. Desta forma, ocorrendo a execução na constância matrimonial, incidirá a garantia prestada apenas sobre o patrimônio pessoal de quem assumir a posição de avalista.

Por derradeiro, e talvez mais controverso, está o regime da separação legal de bens (Art. 1.641, CC ${ }^{57}$ ). As pessoas que se casam tendo de adotar tal regramento viveriam como se apenas existissem patrimônios pessoais, estando sujeitas aos mesmos limites já indicados na separação absoluta; entretanto, por força da Súmula 377 do Supremo Tribunal Federal ${ }^{58}$, haverá a formação de um patrimônio comum do casal.

A polêmica no caso deste regime forma-se pela inconstância da jurisprudência a respeito de quais bens seriam constituintes desta parcela partilhável. Ainda não se pacificou entendimento se este patrimônio seria formado por todos os bens adquiridos na constância do casamento, se apenas pelos bens adquiridos onerosamente, ou ainda, se tão somente pelos bens adquiridos onerosamente e com comprovada contribuição dos cônjuges. Independentemente de quais bens integrarão este patrimônio comum, certo é que deverá se limitar a eficácia do aval à meação desta fração do conjunto de bens.

Feitas estas considerações, reforça-se a ideia de que a eficácia do aval prestado, sem sombra de dúvidas, enfrentará óbices segundo o regime de bens que estiver regulamentando as relações patrimoniais do avalista.

\section{CONSIDERAÇÕES FINAIS}

Levando em conta o que foi apontado, resta claro que os títulos de crédito foram formalizados como meios seguros para facilitar as relações creditícias, que eram carentes de um instrumento palpável para assegurar a existência relação jurídica,

\footnotetext{
57 BRASIL. Código Civil de 2002. Lei no 10.406, de 10 de janeiro de 2002. Brasília, DF: Senado Federal, 2002.

58 BRASIL. Supremo Tribunal Federal. Súmula $n^{\circ}$ 377. Disponível em: < http://www.stf.jus.br/portal/jurisprudencia/menuSumarioSumulas.asp?sumula=4022>. Acesso em: 19 de janeiro de 2020 .
} 
Lima, Taisa Maria Macena de; CARNEIRO, Victor Augusto Souza Antunes. A antinomia entre o aval e a outorga conjugal. Revista Eletrônica Direito e Política, Programa de Pós-Graduação Stricto Sensu em Ciência Jurídica da UNIVALI, Itajaí, v.16, n.2, $2^{\circ}$ quadrimestre de 2021. Disponível em: www.univali.br/direitoepolitica - ISSN 1980-7791.

a obrigação pactuada e, principalmente, viabilizar meios de garantir o cumprimento futuro. Neste contexto, legislação, doutrina e jurisprudência, buscaram estrutura-los de modo a garantir maior segurança jurídica na sua utilização.

Entretanto, diante de uma tentativa de aglomeração de normas no Código Civil, fazendo-se prever a regulamentação básica - e subsidiária - dos títulos de crédito, negligenciou-se diversos princípios cambiários. Em razão da má formulação legislativa, a integração pretendida acabou sendo verdadeiro revés aos títulos de crédito, já que ensejou questões controversas e passíveis de questionamento.

Face esta conjuntura, destacam-se as particularidades e contrapontos de uma das principais polêmicas: a aparente antinomia entre a normatização do aval e a exigência da vênia do cônjuge para prestá-lo. Diz-se aparente, pois, segundo o entendimento que vem sendo construído, as disposições do códex civilista podem conviver, sem que uma seja o completo oposto da outra. A exigência da outorga para prestar o aval não será causa de nulidade, mas sim, denota possível limite na eficácia do aval.

De mais a mais, verifica-se que o Superior Tribunal de Justiça, recentemente, começou a mudar o rumo da jurisprudência nacional. Com o papel de uniformização da jurisprudência nacional, o tribunal superou o embate que ocorria entre suas próprias turmas, e passou a indicar a tendência a unificar o entendimento a respeito da aparente antinomia instaurada pelas disposições do Código Civil.

Com isto, haverá a permanência de ambos os dispostos legislativos: permanecerá sendo exigível a existência da vênia conjugal para a absoluta eficácia do aval prestado, sem que isto, de forma alguma, retire a proteção concedida à família e ao seu patrimônio. E assim, talvez seja esta a solução com maior lógica e mais justa para os jurisdicionados.

De um lado, permanecerá a busca pela segurança jurídica e confiabilidade dos títulos de crédito, impulsionando a fácil circulação de riquezas e permitindo a manutenção do mercado; e de outro, não se afastará a salvaguarda do patrimônio 
Lima, Taisa Maria Macena de; CARNEIRO, Victor Augusto Souza Antunes. A antinomia entre o aval e a outorga conjugal. Revista Eletrônica Direito e Política, Programa de Pós-Graduação Stricto Sensu em Ciência Jurídica da UNIVALI, Itajaí, v.16, n.2, $2^{0}$ quadrimestre de 2021. Disponível em: www.univali.br/direitoepolitica - ISSN 1980-7791.

familiar, sobretudo em casos de ausência da concordância do cônjuge do avalista. Entretanto, cumprirá sempre avaliar e ponderar o regramento de bens que regula o casamento do avalista, já que, apesar de não invalidar do aval prestado, o regime adotado poderá ser fator limitados da eficácia da garantia cambiária, de forma tal, a excluir bens que compõem o patrimônio do casal.

Estando certo destas colocações, é nítido o reestabelecimento - pelo menos o início dele - da credibilidade esperada aos títulos de crédito, sobretudo, daqueles que possuem o aval. Resgata-se a exata confiança objetiva que é fator condicionante a concessão do crédito, possibilitando a continuidade na disseminação das relações embasadas no crédito.

\section{REFERÊNCIAS DAS FONTES CITADAS}

BRASIL. Código Civil de 2002. Lei no 10.406, de 10 de janeiro de 2002. Brasília, DF: Senado Federal, 2002.

BRASIL. Conselho Nacional de Justiça. Enunciado 114. I Jornada de Direito Civil, 2012. Disponível em: < https://www.cjf.jus.br/enunciados/enunciado/751>. Acesso em: 19 de janeiro de 2020.

. Decreto no. 2.044, de 31 de dezembro de 1908. Define a letra de câmbio e a nota promissória e regula as Operações Cambiais. Disponível em: <http://www.planalto.gov.br/ccivil_03/decreto/Historicos/DPL/DPL2044.htm>. Acessado em 15 ago. 2019.

. Decreto no. 57.663, de 24 de janeiro de 1966. Promulga as Convenç̃ões para adoção de uma lei uniforme em matéria de letras de câmbio e notas promissórias.

Disponível

em: <http://www.planalto.gov.br/ccivil_03/decreto/Antigos/D57663.htm>. Acessado em 15 ago. 2019.

- Supremo Tribunal Federal. Súmula $n^{\circ}$ 377. Disponível em: < http://www.stf.jus.br/portal/jurisprudencia/menuSumarioSumulas.asp?sumula= 4022>. Acesso em: 19 de janeiro de 2020.

Superior Tribunal de Justiça, REsp 1526560/MG, Rel. Ministro Paulo De Tarso Sanseverino, Terceira Turma, julgado em 16/03/2017, DJe 16/05/2017.

Superior Tribunal de Justiça, REsp 1633399/SP, Rel. Ministro Luis Felipe Salomão, Quarta Turma, julgado em 10/11/2016, DJe 01/12/2016. 
Lima, Taisa Maria Macena de; CARNEIRO, Victor Augusto Souza Antunes. A antinomia entre o aval e a outorga conjugal. Revista Eletrônica Direito e Política, Programa de Pós-Graduação Stricto Sensu em Ciência Jurídica da UNIVALI, Itajaí, v.16, n.2, $2^{\circ}$ quadrimestre de 2021. Disponível em: www.univali.br/direitoepolitica - ISSN 1980-7791.

Superior Tribunal de Justiça, REsp 1163074/PB, Rel. Ministro Massami Uyeda, Terceira Turma, julgado em 15/12/2009, DJe 04/02/2010.

BULGARELLI, Waldirio. Títulos de Crédito. 14. Ed. São Paulo, Atlas, 1998.

COELHO, Fábio Ulhôa. Manual de Direito Comercial. 20. Ed. São Paulo: Saraiva, 2008.

BRASIL. Conselho Nacional de Justiça. Enunciado 114. I Jornada de Direito Civil, 2012. Disponível em: < https://www.cjf.jus.br/enunciados/enunciado/751>. Acesso em: 19 de janeiro de 2020.

COSTA, Wille Duarte. Títulos de crédito. 4. ed. Belo Horizonte: Del Rey, 2007.

FERNANDES, Jean Carlos. Títulos de crédito: homenagem ao professor Wille Duarte Costa. Belo Horizonte: Del Rey, 2011.

FERNANDES, Jean Carlos. Teoria Contemporânea dos Títulos de Crédito Imperativos principiológicos sob a ótica das teorias pós-positivistas. Belo Horizonte: Arraes Editores, 2012.

GONÇALVES NETO, Alfredo de Assis. Aval - alcance da responsabilidade do avalista. 2. ed. São Paulo: Revista dos Tribunais, 1987.

MAMEDE, Gladston. Direito Empresarial Brasileiro: Títulos de Crédito - Volume 3. 7 ed. São Paulo: Atlas, 2012.

MATTOS, Sílvia Ferreira Persechini. Outorga Conjugal no Aval. Belo Horizonte: Del Rey, 2012.

MENDONÇA, José Xavier Carvalho de. Tratado de Direito Comercial Brasileiro. 2. Ed. Rio de Janeiro: Freitas Bastos, 1934.

RAMOS, André Luiz Santa Cruz. Direito Empresarial Esquematizado. 50 ed. rev., atual e ampla. Rio de Janeiro: Forense, 2015, p. 445.

ROCHA, Pedro. A Outorga Conjugal e o Aval: encontros e desencontros entre legislação e jurisprudência. Belo Horizonte: D’placido, 2014.

ROSA JÚNIOR, Luiz Emygdio da. Títulos de Crédito. 4. Ed. Rio de Janeiro: Renovar, 2006.

SZTAJN, Rachel; VERÇOSA, Haroldo Malheiros Duclerc. A disciplina do aval no novo Código Civil. Revista de direito mercantil, industrial, econômico e financeiro n. 128. São Paulo: Malheiros, outubro-dezembro/ 2002, p. 33-40.

TOMAZETTE, Marlon. Curso de Direito Empresarial: Títulos de Crédito - Volume 2. 5 ed. São Paulo: Atlas, 2014.

RECEBIDO EM: MAI/2020

APROVADO EM: MAR/2021 